ROMAN SOWA ${ }^{1,2}$, ANDRZEJ KOWAL ${ }^{1}$, ELZBIETA ROGA ${ }^{1}$, SEBASTIAN ARABASZ3 ${ }^{3}$ ANDRZEJ DZIEDZIC ${ }^{4}$, IRENA DUL ${ }^{5}$, MAGDALENA PARLINSKA-WOJTAN ${ }^{1 *}$

${ }^{1}$ Facility for Electron Microscopy \& Sample Preparation, Centre for Microelectronics and Nanotechnology, Department of Mathematics and Natural Sciences, University of Rzeszow, Rzeszow, Poland, ${ }^{2}$ MTU Aero Engines Polska, Jasionka, Poland, ${ }^{3}$ Labsoft SA, Warszawa, Poland, ${ }^{4}$ Centre for Innovation \& Knowledge Transfer, University of Rzeszow, Poland, ${ }^{5}$ WSK "PZL-Rzeszow" S.A. Rzeszow, Poland
Scientific paper

UDC:620.181:669.18-156

doi:10.5937/ZasMat1503261S

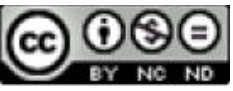

Zastita Materijala 56 (3)

$261-268$ (2015)

\title{
Influence of double solution treatment on hardness in 17-4 PH steel
}

\begin{abstract}
The investigated material is a corrosion-resistant, $\mathrm{Cu}$ precipitation hardened steel 17-4PH, which undergoes a macroscopic contraction, as a result of applying the following heat treatment: double solution treatment at $1028^{\circ} \mathrm{C}$ for $1 \mathrm{~h}$ (condition A), ageing at $540^{\circ} \mathrm{C}$ for $4 \mathrm{~h}$ (condition H1025). The second solution treatment at $1028^{\circ} \mathrm{C}$ was found to eliminate the retained austenite, being the evidence of a completely finished martensitic transformation. Indeed, the only phase identified in all samples was fcc lath martensite exhibiting a parallel striped structure. Unfortunately, this additional heat-treatment operation leads likewise to significant and irregular grain growth, which consequently causes a drop in material hardness. In addition to the martensitic phase, in the unaged samples, a $\delta$-ferrite phase could be identified by TEM and electron diffraction, which is favorable for ductility and toughness of the material. In all samples, non-coherent $f c c-N b C$ precipitates identified by electron diffraction and EDX mapping having sizes up to $70 \mathrm{~nm}$ were found.
\end{abstract}

Keywords: steel $17-4 \mathrm{PH}$, retained austenite reduction, $\mathrm{Cu}$ precipitation hardening, $\delta$-ferrite, $\mathrm{NbC}$ precipitates, TEM.

\section{INTRODUCTION}

17-4PH martensitic precipitation-hardened stainless steel is widely used in aerospace and other high-technology industries. High strength, ease of fabrication, good ductility and corrosion resistance belong to the most important properties of this steel. It is used for applications such as gears, high strength shafts, valves, chemical process equipment, nuclear reactor components and jet engine parts. The major advantage of precipitation-hardened steels is that they can be supplied in a solution treated condition being thus directly machinable. After machining or a different fabrication method, a low temperature heat treatment can be applied to modify its properties mainly due to precipitation of highly dispersed particles in the matrix [1]. The 174 steel while being annealed at temperatures between 1040 and $1065^{\circ} \mathrm{C}$ has predominantly an austenitic structure. Then, upon cooling to room temperature, it undergoes a diffusionless martensitic transformation [2]. The resulting martensitic structure exhibits a low hardness of about C35 [3],

\footnotetext{
${ }^{*}$ Corresponding author: M. Parlinska-Wojtan

E-mail: magdalena.parlinska@ur.edu.pl

Paper received: 13. 02. 2015.

Paper accepted: 07. 04. 2015.

Paper available on the website: www.idk.org.rs/casopis
}

a subsequent aging may however improve it. Since the material has a complex chemistry, as shown in Table 1, the ageing involves various microstructural changes including carbide formation, copper precipitation, as well as reversed austenite formation. Investigations on the impact of these microstructural changes on mechanical properties are reported in the literature [4-8].

The $17-4 \mathrm{PH}$ stainless steel is most often supplied from the mill in solution-annealed unaged condition, labeled as "Condition A", having a microstructure composed of low carbon martensite and up to several volume percent of $\delta$-ferrite stringers $[3,4,6]$. The influence of $\delta$-ferrite on the mechanical properties has been described in literature [9-11]. Zheng [12] claimed that the presence of $\delta$-ferrite deteriorates the toughness of hot rolled $\mathrm{Cr}-\mathrm{Ni}$ steels. The martensite phase, in the solutionannealed condition, consists of a lath structure with a very high density of dislocations and contains a homogeneous distribution of all solute atoms in a supersaturated solid solution [6,13]. Moreover, Dong [14] observed in the microstructure of the 17$4 \mathrm{PH}$ steel extensive micro twins and slip lines across the martensite laths. Subsequent aging treatment of the solid solution phase in the temperature range from 482 to $621^{\circ} \mathrm{C}$, leads to a precipitation hardening effect due to the formation of a sub-microscopic, uniformly distributed copperrich phase. In this investigation, $17-4 \mathrm{PH}$ steel was 
subjected to a second solution treatment, which is not foreseen for this material in the normalized process. The current studies show that the steel behaves unpredictably, after the applied heat-treatment, showing a drop of hardness and macroscopic shrinking. Thus the aim of present work is to investigate the influence of the second solution treatment on microstructural modifications of $17-4 \mathrm{PH}$ steel and on its mechanical properties such as hardness. The microstructural aspects will be investigated by means of XRD and electron microscopy and the macroscopic behavior includes shrinking and changes in hardness values.

\section{EXPERIMENTAL PROCEDURES}

The analyzed material was a bulk stainless steel 17-4 PH alloy, which was subjected to several subsequent heat-treatments. Table 1 summarizes the treatments applied to the 17-4 $\mathrm{PH}$ samples, explaining the designations Condition $A$, Condition $A A$ and $\mathrm{H} 1025$, which are used hereafter. Sample 1 was in the as-received condition solution solution-treated at $1028^{\circ} \mathrm{C}$ by the supplier. Prior to machining the material was again solution heattreated - Sample 2. Sample 3 was subsequently aged and Sample 4 was solution treated again.

Table 1 - Heat treatments applied to the 17-4 PH steel samples and the resulting hardness values.

\begin{tabular}{|c|c|c|c|}
\hline Sample 1 & Sample 2 & Sample 3 & Sample 4 \\
\hline $\begin{array}{c}\text { Condition } \\
\text { A }\end{array}$ & $\begin{array}{c}\text { Condition } \\
\text { AA }\end{array}$ & $\begin{array}{l}\text { Condition } \\
\text { AAH1025 }\end{array}$ & $\begin{array}{c}\text { Condition } \\
\text { AAH1025+A }\end{array}$ \\
\hline \multicolumn{4}{|c|}{ Condition $\mathrm{A}=$ solution treatment at $1028 \mathrm{C}$ for $1 \mathrm{~h}$} \\
\hline \multicolumn{4}{|c|}{ Condition $\mathrm{H} 1025=$ ageing at $540 \mathrm{C}$ for $4 \mathrm{~h}$} \\
\hline $26[\mathrm{HRC}]$ & $23[\mathrm{HRC}]$ & $26[\mathrm{HRC}]$ & $23[\mathrm{HRC}]$ \\
\hline
\end{tabular}

The XRD diffractograms were measured on a Bruker D8 Advanced diffractometer equipped with $\mathrm{Da}$ Vinci. The hardness measurements were performed by the Rockwell method. For scanning electron microscopy (SEM) observations, the samples were first mirror polished and then etched for 2 minutes in a mixture of ethanol $100 \mathrm{ml}, \mathrm{HCl} 5 \mathrm{ml}$ and 1 gram of picric acid to reveal their microstructure. The SEM observations were carried out on an FEI Qunta 3D 200i SEM/FIB dual beam equipped with a tungsten cathode. In order to visualize the internal microstructure with TEM, thin 10x20 $\mu \mathrm{m}$ lamellas were prepared at chosen locations by the focused ion beam technique (FIB). The lamellas were cut in the direction perpendicular to the surface of the polished SEM samples. The TEM observations were performed with an FEI Tecnai Osiris (S)TEM operating at $200 \mathrm{kV}$, equipped with a high-brightness $\mathrm{X}$-FEG gun and having a point resolution of $2.5 \AA$. The chemical analyses of the precipitates were made using Super-EDX detector.

\section{RESULTS}

\subsection{XRD Phase analysis}

The X-ray diffraction patterns measured in the $2 \theta$ range from 38 to $120^{\circ}$ are shown in Fig. 1. For all samples, the diffractograms clearly indicate only the presence of $\mathrm{Fe}-\mathrm{Cr}-\mathrm{Ni}$ martensite phase. As the samples are polycrystalline, peaks from different crystallographic orientations are observed.

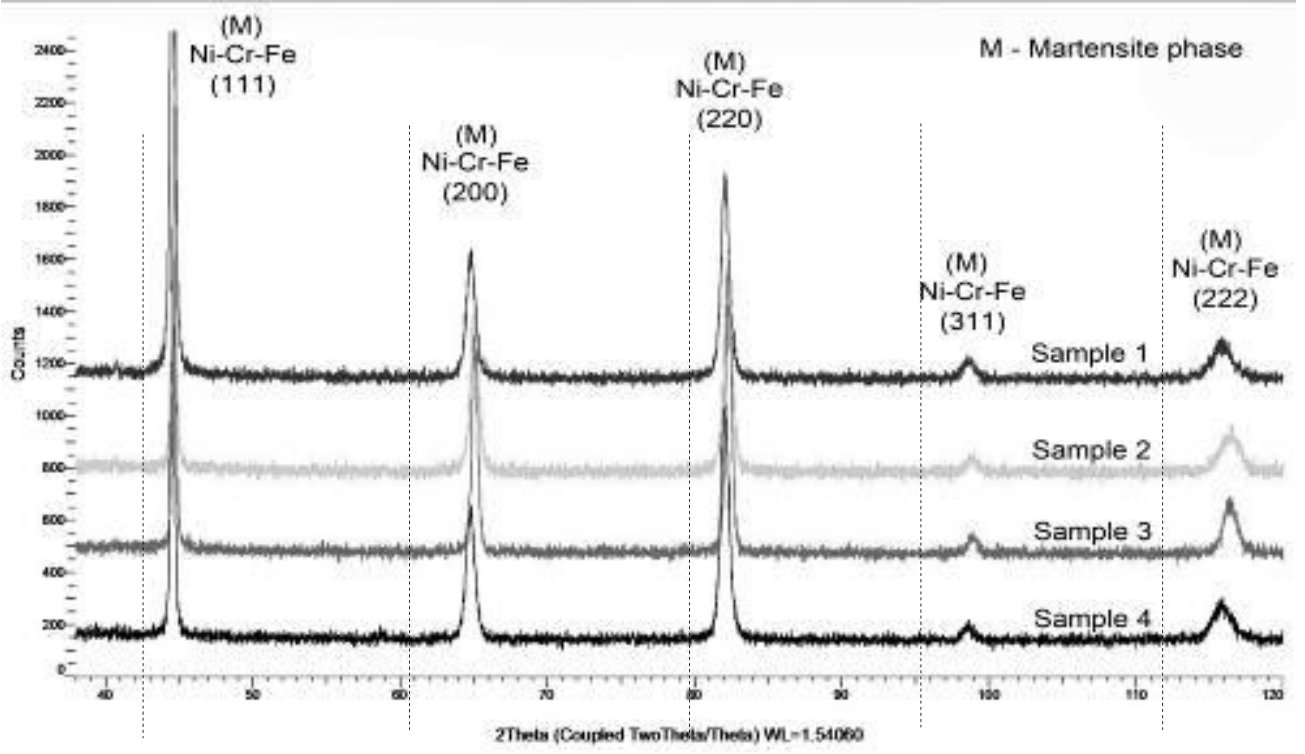

Figure 1 - XRD patterns of all four samples with peaks corresponding to the Ni-Cr-Fe martensite phase. No traces of retained austenite were observed 
No peaks indicating the presence of retained austenite are visible. The martensite in Sample 1 and 4 has a fcc structure (space group Fm-3m), with a lattice parameter of $a=0.2877 \mathrm{~nm}$, estimated from XRD phase analysis. The second solution treatment as well as aging, corresponding to Samples 2 and 3 , caused a rigid shift of the diffraction peaks towards higher angles. This results from contraction of the lattice parameter, which decreased to $a=0.2870 \mathrm{~nm}$. For Sample 4, which under- went a solution treatment after aging, the diffraction peaks shifted back to initial Bragg angles, thus matching Sample 1. This strongly suggests that the process of shrinkage and expansion of the lattice parameter can a reversible process.

\subsection{Metallography by SEM imaging}

Figure 2 presents SEM images, which show the evolution of the sample microstructure following applied heat treatment.
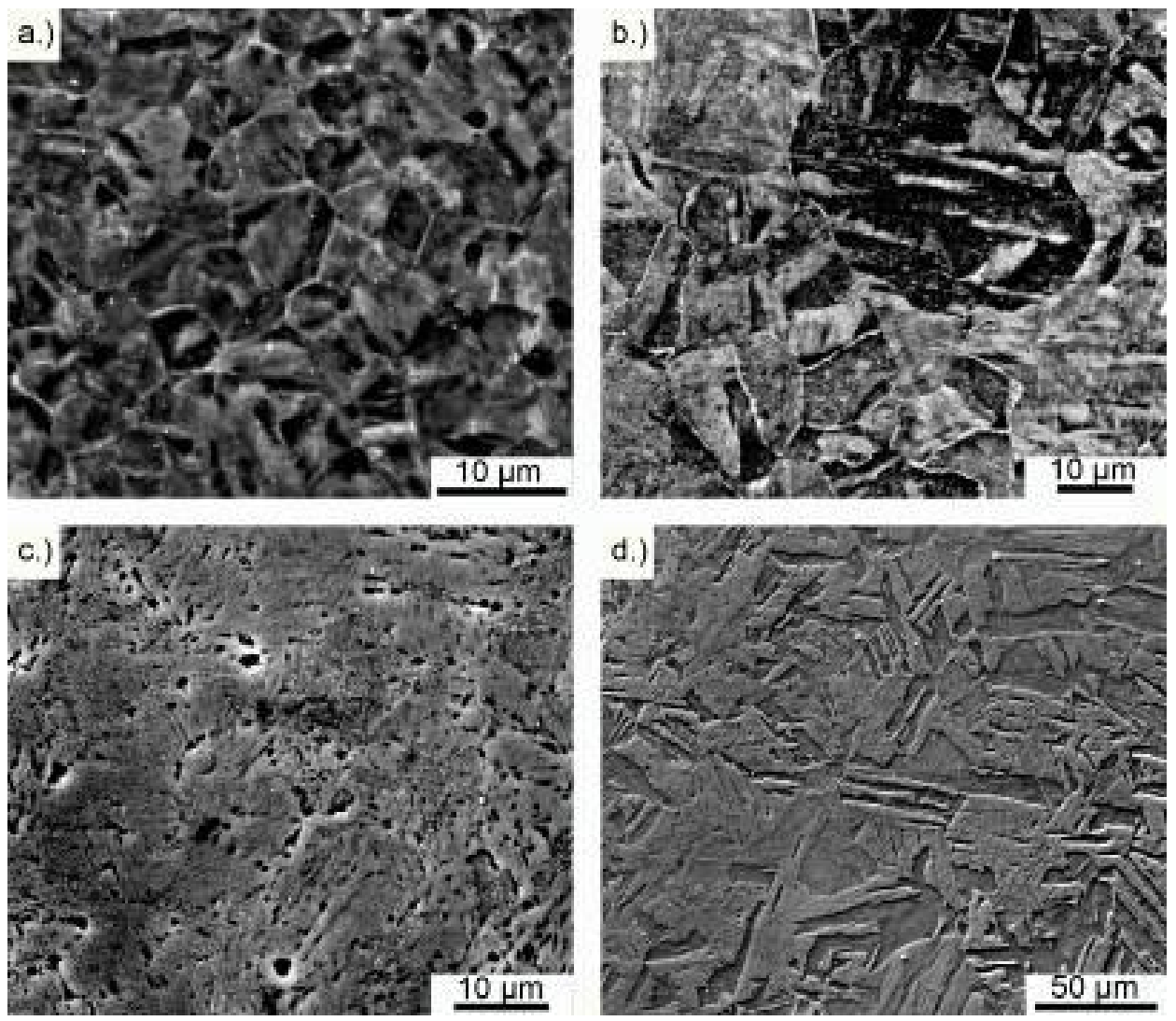

Figure 2 - SEM micrographs of polished and chemically etched sample cross-sections:

(a) Sample 1, condition A; (b) Sample 2, condition $A+A$; (c) Sample 3, condition $A+A+H 1025$,

(d) Sample 4, conditionA $+A+H 1025+A$. Please note that scales on the images are different

The grains in Sample 1, Figure 2(a), have a regular shape and their size is in the range between $5-10 \mathrm{~m}$, while in other samples the grains exceed the size of $40 \mathrm{~m}$, and individual grains vary significantly in shape. Furthermore, similarities in the microstructure of sample 2, Figure 2 (b), and sample 4, Figure 2 (d), such as the presence of lath martensite in form of parallel groups of laths, can be clearly observed. Their appearance is the result of a completely finished diffusionless martensitic transformation.

Condition $A$ and $A A$ equiaxial martensite laths surrounded by retained austenite grains with different grain sizes, which is not visible in the XRD diffractogramms due to their too small sensitivity to such a small volume fraction phase. Upon subsequent aging there is a dramatic change in microstructure. Indeed, the grains etched in a different way, most probably due to intergranular $\mathrm{Cu}$ precipitation.

\subsection{Hardness measurements}

Table 1 presents the results of hardness measurements, which show a decrease in hardness for samples 2 and 4, compared to sample 1 . The data shows that the values are much smaller than 
expected [11,16]. Furthermore, following $\mathrm{AAH}$ treatment increases the hardness as expected. However, the hardness increased only up to the value measured in sample 1 , which does not meet the requirements for a material subjected to the standard heat treatment $\mathrm{A}+\mathrm{H}$. The reason for the observed variation in the sample hardness is most probably related to the microstructural changes and the precipitation of Cu-rich phase. It is therefore essential to undertake TEM and STEM analysis.

\subsection{TEM/STEM microstructural characterization}

Since the microstructural characterization performed in the scanning electron microscope allowed only to determine the grain size and visualize the presence of lath martensite, the (S)TEM analysis of the samples was conducted.
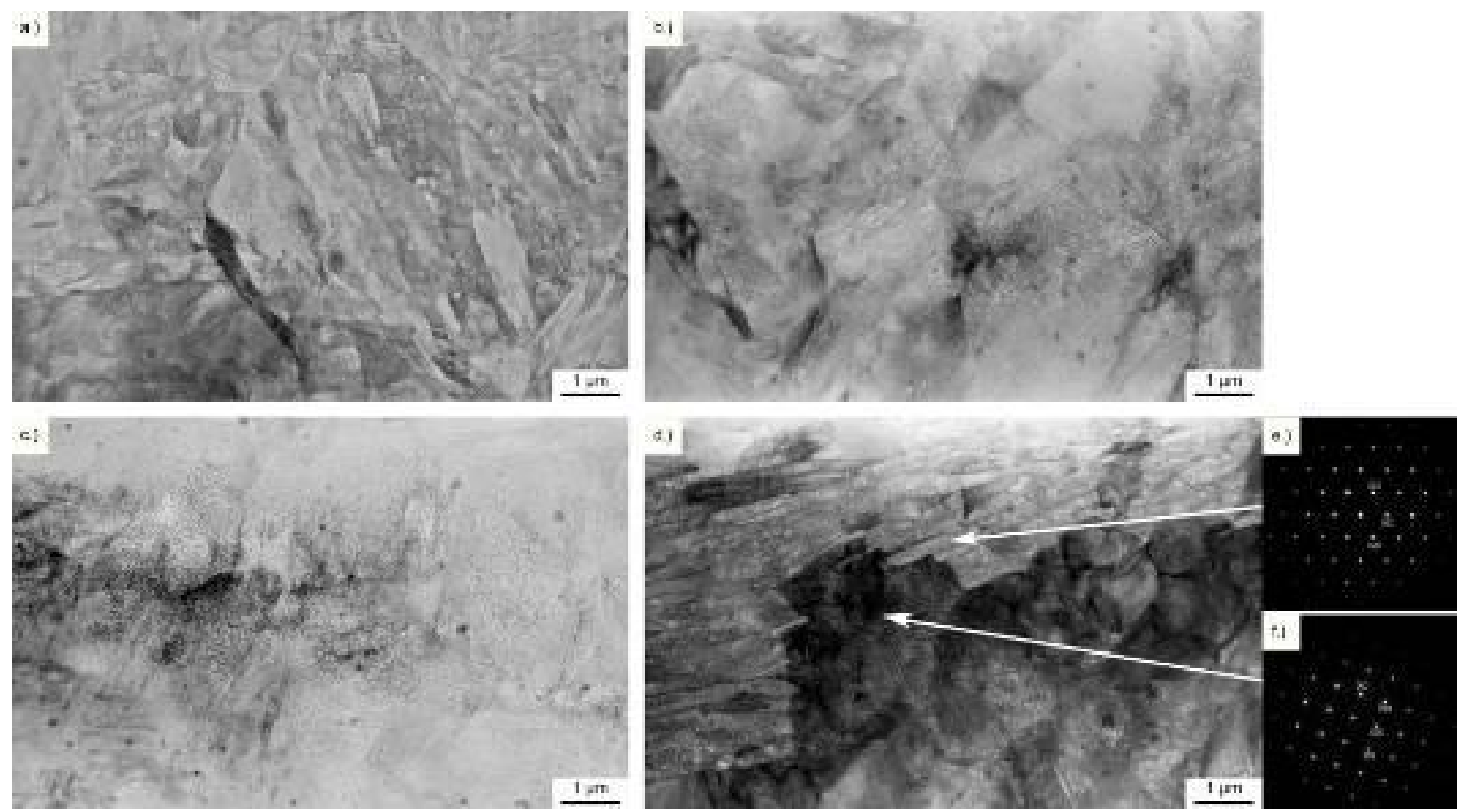

Figure 3 - STEM BF micrographs taken for all four samples presenting their respective overviews:

(a) Sample 1, condition A; (b) Sample 2, condition $A+A$; (c) Sample 3, condition $A+A+H 1025$,

(d) Sample 4, condition $A+A+H 1025+A$, (e), (f) Diffraction patterns taken from two different grains identifying the martensite microstructure.

Although the FIB lamella are cut locally and represent a limited area of the whole sample, the advantage of the dual beam machines is that the cut may be done from a representative part of the sample first observed on SEM images. However, the lamellas have to be always analyzed with the reference to original metallography sections, showing much larger areas of the samples. As shown in STEM images acquired on the BF detector (Figure 3), the dominant phase in the material is lath martensite containing a high density of dislocations, whose presence was also confirmed by XRD data. Furthermore, the fcc Fe$\mathrm{Cr}-\mathrm{Ni}$ martensite phase was also confirmed with SAED diffraction patterns. Two examples are given in Figure 3(e) and (f), where patterns were taken from two different areas indicated by white arrows.
The change in lattice parameter detected in XRD is too small to become readily visible on TEM diffraction patterns. However the martensite phase in various conditions shows clear variability. There are also precipitates of round shape and the diameter in the range from 30 to $70 \mathrm{~nm}$, which are the most numerous on the sample in condition $A+A$. Their chemical analysis by EDX shows maps of $\mathrm{Fe}, \mathrm{Cr}, \mathrm{Nb}$ and $\mathrm{C}$ distribution, Figure 4, provides further confirmation. Indeed, the region corresponding to the precipitate is depleted in iron and chromium Figure 4(c) and (e), enriched in carbon and contains $\mathrm{Nb}$ Figure 4(d) and (f). Furthermore, the STEM image acquired on HAADF detector shows lighter intensity in the precipitate area, indicating its higher atomic number than that in the matrix. 

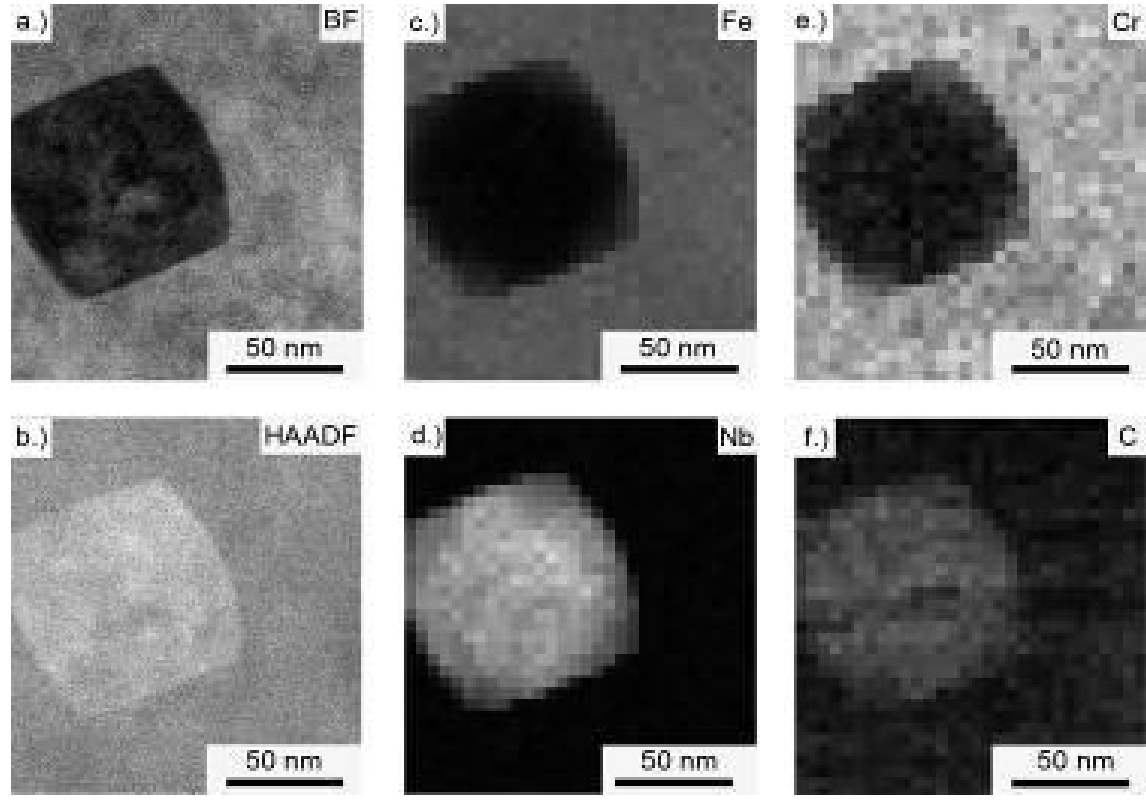

Figure 4 - STEM images with corresponding EDX maps of NbC precipitates present the microstructure of all 17-4 PH steel samples: (a) BF and (b) HAADF image; (c) EDX map of Fe; (d) EDX map of Nb;

(e) EDX map of $C r$; (f) EDX map of $C$.

The bright and dark field images and microdiffraction pattern of the $\mathrm{NbC}$ precipitates are provided in Figure 5. According to the pattern, they were identified as $f c c$ niobium carbide phase. Following the aging treatment, Figure 3(c), additionally a high density of $\mathrm{Cu}$ nanoprecipitates was grown in consistence with reported data. They are barely seen as whitish graining/texture. The subsequent $A$ treatment resulted in their dissolution into the matrix.
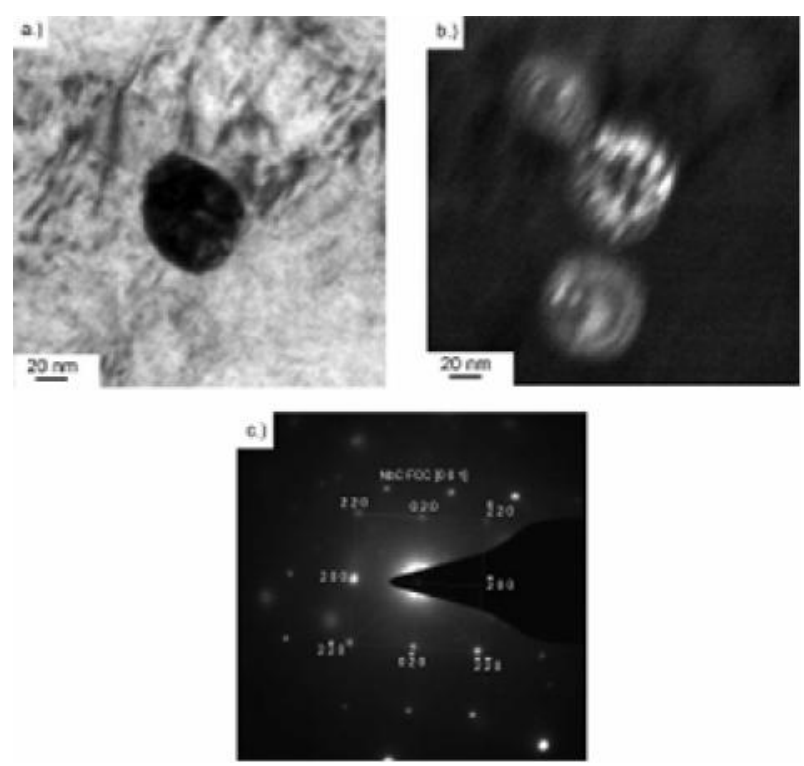

Figure 5 - TEM images of $\mathrm{NbC}$ precipitates observed in all samples: (a) bright field image;

(b) dark field image; (c) corresponding microdiffraction pattern.
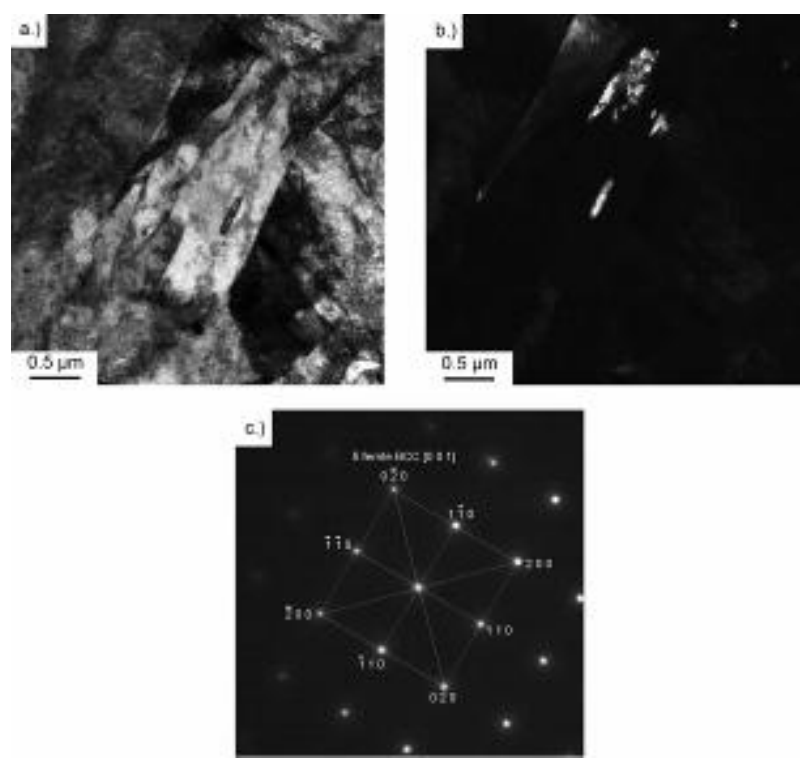

Figure 6 - TEM images of $\delta$-ferrite phase in sample 1: (a) bright field image; (b) dark field image; (c) corresponding selected area diffraction pattern

The bright field TEM image in Figure 6 shows that the as-received, unaged $17-4 \mathrm{PH}$ also comprise the $\delta$-ferrite phase. The dark field image Figure 6 (b) depicts that it has a needle-like shape, elongated in the same direction as the martensite grains. The SAED pattern Figure 6 (c) taken from the $\delta$-ferrite phase confirms its $f c c$ structure.

\section{DISCUSSION}

The XRD analysis revealed the presence of $\mathrm{Ni}$ $\mathrm{Cr}-\mathrm{Fe}$ lath martensite phase as the only phase in all 4 samples, independently of the heat treatment 
procedures. These results are in partial agreement with those obtained by Bhambroo [15], who in the case of the solution treated sample, also confirmed a complete transformation from austenite to the martensite phase.

From the XRD phase identification performed in the aged sample 3 it can be concluded, that the double solution treatment prior to the aging, lead to a complete martensitic transformation where all the austenite was transformed leaving behind no retained austenite. Retained austenite was indeed identified by Wang [16] and Bhambroo [15] in samples subjected to a single solution treatment before aging. According to their measurements, with increasing aging time, the content of retained austenite in the material increases, which negatively affects the mechanical properties of the material. The XRD diffractograms upon closer analysis show a shift of the diffraction peaks towards higher $2 \theta$ angles for the Sample $A+A$ i.e. subjected to the double solution treatment. This shift remains after subsequent aging. Only the following solution treatment restores the peaks position in the XRD diffractogram to their original position. The combination of the solution treatment processes may cause stress in the material entailing the change in the lattice parameter. Indeed, if the lattice parameter of the structure decreases, the material density is increased and thus its volume is reduced. This is most probably accompanied by the occurrence of shear stress. In the initial condition A the structure is martensitic with some $\delta$-ferrite phase. After the second solution treatment, condition $\mathrm{AA}$, a precipitation of $\mathrm{Cu}$ on dislocations present in martensite occurs. This is a fine dispersion phase, which can induce stress in the structure. After the AAH treatment the $\mathrm{Cu}$ dispersion phase remains. After the subsequent solution treatment, condition AAHA, the $\mathrm{Cu}$ is again solved in the structure. Thus the observed increase and decrease of the lattice parameters seems to be a reversible process, which depends on the type and sequence of the heat treatment procedures.

According to Table 1, the hardness of the 17$4 \mathrm{PH}$ stainless steel depends on the heat treatment procedures. The SEM pictures, Figure 2, show grain growth in the material subjected to additional heat treatment processes, which is at the origin of hardness decrease from 26 to $23 \mathrm{HRC}$. This is in agreement with the Hall-Petch law, which relates grain size to the hardness of materials $[17,18]$. In the case of Sample AAHs, which was subjected to the precipitation hardening process, the hardness increased to $26 \mathrm{HRC}$, which is however lower than expected. The microstructural features of the etched surfaces of the sample cross sections are similar to the observations of other authors $[15,19]$. In Figure 2(b) and (c) the presence of lath martensite in form of parallel stripes in different crystallographic orientation, can be clearly observed. Moreover Figure 2 (a) shows finegrained microstructure of sample 1 , which has much smaller grains than other samples. If this structure is subjected to aging, the combination of precipitation and a relatively small grain size should lead to a significant hardness increase. The hardness of the steel 17-4PH in H1025 condition measured by Aydemir [19] was 37.2 HRC, which means that our sample in condition $\mathrm{A}+\mathrm{A}+\mathrm{H} 1025$ has a significantly underestimated hardness value (26 HRC), Table 1. One of the possible reasons for such a low hardness is this additional process of solution treatment, which was applied to eliminate the retained austenite but caused a significant grain growth. This large grain size of $40 \mathrm{~m}$ contributes to the observed low hardness. Thus, it is evident that even the aging treatment leading to a uniform precipitation of $\mathrm{Cu}$ in the $\mathrm{Fe}-\mathrm{Cr}-\mathrm{Ni}$ matrix will only slightly enhance the hardness, as the grain growth after the second solution treatment was too important.

The STEM photos showing the local microstructure of the steels, Figure 3 , confirm the results obtained by the XRD and SEM. The main phase observed in all samples is lath martensite with a high density of dislocations, also observed by other authors $[10,20]$. The diffraction patterns, Figure 3 (e) and (f) showed, that it has a fcc structure, which considering the negligible carbon content, is agreement with the studies conducted by Sherby [21]. Cambell and Fink [22] have shown that the fcc structure is the stable structure in steels with carbon contents in the range between 0 to 0.6 wt. $\%$ with the c/a ratio equal to one. Moreover, in the microstructure of Sample 3, Figure 3(c), evenly distributed nanoprecipitates having sizes varying between $20-30 \mathrm{~nm}$ are present, which increase the hardness of the material. According to other studies $[5,23]$, these are copper nanoprecipitates, which during the aging process at a temperature approximately $500^{\circ} \mathrm{C}$, grow from 4 to $30 \mathrm{~nm}$. While growing, these precipitates undergo a structural transformation from fcc structure being coherent with the matrix to fcc structure, which consequently leads to the loss of coherence. Detailed TEM analysis did not show the presence of retained austenite in the microstructure of all samples, which was previously observed by other authors [15]. However, the TEM analysis allowed us to identify other phases and precipitates. One of them was the $\delta$-ferrite phase observed in the samples subjected to the process of solution treatment, which is consistent with reports of Rack and Kalisz [4]. Schäfer claims, that the relatively soft delta ferrite increases the ductility and toughness of the martensitic steel [9]. Figure 6 (b) presents a dark 
field TEM image of the $\delta$-ferrite phase, which consists of needles elongated in the same direction as the lath martensite. Alkan [10] found that increasing the volume of $\delta$ ferrite reduces the Brinnel hardness, but on the other hand increases the microhardness of lath martensite. Alkan findings might additionally explain the hardness decrease of the investigated material.

Figure 4 and Figure 5 evidence the presence of niobium carbides in all tested samples, which were also confirmed by Wang [16] and Wu and Lin [24]. Microdiffraction patterns showed that these precipitates have an $f C c$ structure and a lattice parameter $\mathrm{a}_{\mathrm{NbC}}=0.44 \mathrm{~nm}$. The EDX chemical analysis confirmed, that the precipitates are enriched in carbon and niobium, and depleted in chromium and iron, which are the main components of the matrix. $\mathrm{NbC}$ precipitates, with a lattice parameter $\mathrm{a}_{\mathrm{NbC}}=$ $0.44 \mathrm{~nm}$ were also observed by Bajguirani [7] in 15$4 \mathrm{PH}$ steel having a similar composition and microstructure as the $17-4 \mathrm{PH}$ steel.

\section{CONCLUSIONS}

This investigation was conducted on a corrosion-resistant, Cu precipitation hardened steel 17$4 \mathrm{PH}$, subjected to several heat treatment operations. The main phase in all samples, independently of the heat treatment, is a Fe-Cr-Ni fcc lath martensite. The presence of retained austenite was not observed in any of the samples, which is the evidence that the martensite transformation is completely finished. The lattice parameters decrease due to the double solution treatment, which can contribute to the macroscopic shrinking of the material. In the solution treated samples traces of a $\delta$-ferrite phase, having an elongated structure parallel to the martensite laths, were identified. The XRD combined with hardness measurements and SEM observations, show, that the absence of retained austenite can be of benefit for the mechanical properties of $17-4 \mathrm{PH}$ steel, however the second solution treatment, causing the disappearance of retained austenite, causes simultaneously an important grain growth, and is thus detrimental to the hardness of the obtained materials.

The TEM and EDX analysis reveals the presence of $\mathrm{Nb}$ carbides with sizes in the order between $50-200 \mathrm{~nm}$ in all samples.

\section{Acknowledgments}

The authors gratefully acknowledge WSK "PZL Rzeszow" company for providing the tested materials. Project UDA-RPPK.01.03.00-18-052/12-00 is acknowledged.

\section{REFERENCES}

[1] C.N. Hsiao, C.S. Chiou, J.R. Yang, (2002) Aging reactions in a 17-4 $\mathrm{PH}$ stainless steel, Mater. Chem. Phy. 74, 134-142.

[2] K. V. Kurdyumov, (1997) Nature of diffusionless (martensite) transformations, Met. Sci. Heat Treat., 39, Nos. 1-2, 70-76.

[3] W.F. Smith, (1993) Structure and Properties of Engineering Alloy, 2nd Edition, McGraw-Hill, New York, USA.

[4] H.J. Rack, D. Kalish, (1974) The Strength, Fracture Toughness, and Low Cycle Fatigue Behavior of 174 PH Stainless Steel, Metall. Trans. 5, 1595-1605.

[5] N. Maruyama, M. Sugiyama, T. Hara, H. Tamehiro, (1999) Precipitation and Phase Transformation of Copper Particles in Low Alloy Ferritic and Martensitic Steels, Mater. Trans. JIM 40, 268-277.

[6] U.K. Vishwanathan, S. Banerjee, R. Krishnan, (1988) Kinetics of precipitation in 17-4 PH stainless Steel, Mater. Sci. Eng. A 104, 181-189.

[7] H.R.H. Bajguirani, (2002) The effect of ageing upon the microstructure and mechanical properties of type 15-5 PH stainless steel, Mater. Sci. Eng. A 338, 142-159.

[8] J.H. Wu, C.K. Lin, (2003) Tensile and Fatigue Properties of 17-4 PH Stainless Steel at High Temperatures, J. Mater. Sci. 38, 965-971.

[9] L. Schäfer, (1998) Influence of delta ferrite and dendritic carbides on the impast and tensile properties of a martensitic chromium steel, J. Nucl. Mater. 262, 1336-1339.

[10] G. Alkan, D. Chae, S.-J. Kim, (2013) Effect of $\delta$ ferrite on impact property of hot-rolled $12 \mathrm{Cr}-\mathrm{Ni}$ steel, Mater. Sci. Eng. A, 585, 39-46.

[11] P. Wang, S.P. Lu, N.M. Xiao, D.Z. Li, Y.Y. Li, (2010) Effect of delta ferrite on impact properties of low carbon $13 \mathrm{Cr}-4 \mathrm{Ni}$ martensitic stainless steel, Mater. Sci. and Eng. A 527, 3210-3216.

[12] H. Zheng, X.Y. Ye, J.D. Li, L.Z. Jiang, Z.Y. Liu, G.D. Wang, B.S. Wang, (2010) Effect of carbon content on microstructure and mechanical properties of hotrolled low carbon $12 \mathrm{Cr}-\mathrm{Ni}$ stainless steel, Mater. Sci. Eng. A 527, 7407-7412.

[13] M. U. Islam, G. Campbell, and R. Hsu, (1989) Fatigue and Tensile Properties of EB Welded 17-4 PH Steel, Welding Journal, 68, 45-50.

[14] H. Dong, M. Esfandiari, X. Y. Li, (2008) On the microstructure and phase identification of plasma nitrided 17-4PH precipitation hardening stainless steel, Surf. \& Coat. Technol. 202, 2969-2975.

[15] R. Bhambroo, S. Roychowdhury, V. Kain, V. S. Raja, (2013) Effect of reverted austenite on mechanical properties of precipitation hardenable 17-4 stainless steel Mater. Sci. Eng. A 568, 127133.

[16] J. Wang, H. Zou, C. Li, Y. Peng, S. Qiu, B. Shen, (2006) The microstructure evolution of type 17-4PH stainless steel during long-term aging at 350C, Nuclear Engineering and Design 236, 2531-2536. 
[17] O.E. Hall, (1951) The Deformation and Ageing of Mild Steel: III Discussion of Results, Proc. R. Lond. B64, 474

[18] N.J. Petch, (1953) The cleavage strength of polycrystals, J. Iron Steel. Inst. 174(1), 25

[19] B. Aydemir, L. Yagmur, S. Fank, (2010) Hysteresis errors of commonly used sensor materials, Measurement 43, 792-796.

[20] J.H. Wu, Ph.D., (2003) High-Temperature mechanical properties, fatigue and fracture behaviour of 17-4 PH stainless steel, Department of Mechanical Engineering, National Central University.
[21] O. D. Sherby et al., (2007) The c/a Ratio in Quenched Fe-C and Fe-N Steels - A Heuristic Story, Materials Science Forum 539-543, 215-222.

[22] W. L. Fink, E. D. Campbell, (1926) Influence of heat treatment and carbon content on the structure of pure iron carbon alloys, Trans. Am. Soc. Steel Treat, 9, 717-752.

[23] P.J. Othen, M.L. Jenkins, W.J. Phythian, (1991) High-resolution electron microscopy studies of the structure of $\mathrm{Cu}$ precipitates in $\alpha$-Fe, Phil. Mag. Lett. $64,450$.

[24] J.H. Wu, C.K. Lin, (2005) Tensile and Fatigue Properties of 17-4 PH Stainless Steel at High Temperatures, Mater. Sci. Eng. A, 390, 291-298.

\section{IZVOD}

\section{UTICAJ DVOSTRUKOG TRETMANA RASTVOROM NA TVRDOĆU 17-4PH ČELIKA}

Istraživan je materijal na korozionu otpornost, taloženjem $\mathrm{Cu}$ na kaljeni čelik 17-4PH, koja prolazi kroz makroskopsku kontrakciju, kao rezultat primene sledećih tretmana toplotom: dupli tretman rastvorom na $1028^{\circ} \mathrm{C}$ tokom $1 \mathrm{~h}$ (uslov A), starenje na $540^{\circ} \mathrm{C}$ u toku $4 \mathrm{~h}$ (uslov H1025). Drugim tretmanom rastvorom na $1028^{\circ} \mathrm{C}$, utvrđeno je da se eliminiše zaostala austenitna struktura, što kao dokaz imam potpunu martenzitnu transformaciju. Zaista, identifikovana je u svim uzorcima samo faza martenzitne paralelne prugaste strukture. Nažalost, ovaj dodatni toplotni tretman dovodi do značajnog, isto tako $i$ nepravilnog rasta zrna, što posledično dovodi do smanjenja tvrdoće materijala. Pored martenzitne faze, koja nije ostarila na uzorcima, faza $\delta$-ferita može se prepoznati po TEM i elektronskoj difrakciji, što pogoduje duktilnosti $i$ žilavosti materijala. U svim uzorcima, ne-koherentna fcc-NbC precipitacija prepoznaje se po elektronskoj difrakciji i EDX mapiranju zrna do veličine $70 \mathrm{~mm}$, koja su pronađena.

Ključne reči: čelik 17-4PH, smanjenje austenitne redukcije, Cu vezivanje, $\delta$-ferit, NbC taloženje, TEM.

Naučni rad

Rad primljen: 13. 02. 2015.

Rad prihvaćen: 07. 04. 2015.

Rad je dostupan na sajtu: www.idk.org.rs/casopis 